\title{
Reactions of Some Varieties of Pearlmillet, Pennisetum glaucum (Linn.) R. Br. emend Stuntz. to Rice Moth, Corcyra cephalonica Staint.
}

Anita Sharma ( $\sim$ gauris307@gmail.com )

Sri Karan Narendra Agriculture University, Jobner

K C Kumawat

Sri Karan Narendra Agriculture University, Jobner

S K Khinchi

Sri Karan Narendra Agriculture University, Jobner

\section{Research Article}

Keywords: Rice moth, Corcyra cephalonica, Adult emergence, Damage, Varieties

Posted Date: October 12th, 2021

DOI: https://doi.org/10.21203/rs.3.rs-849502/v2

License: (c) (1) This work is licensed under a Creative Commons Attribution 4.0 International License.

Read Full License 


\section{Abstract}

Ten varieties of pearlmillet (RHB-173, RHB-177, MPMH-17, HHB-67, Pro Agro-9450, Pro Agro-9001, Pioneer $86 \mathrm{~m}$ 86, Pioneer $86 \mathrm{~m}$ 84, Pioneer $86 \mathrm{~m} 38$ and Raj-171.) were evaluated for reaction to Corcyra cephalonica Staint. in the laboratory conditions. The adult emergence $\left(\mathrm{F}_{1}\right)$, weight losses and susceptibility index in these varieties were ranged from 9.33-32.00, 10.44-31.69\% and $2.77-6.82$, respectively, the minimum in Pioneer $86 \mathrm{~m} 86$ and maximum in Raj-171; other varieties were in the middle order. The seed damage recorded in different varieties ranged from $23.67-75.84 \%$, the minimum in Pioneer 86 m 86 (23.67\%), Pro Agro-9450 (25.55\%) and Pro Agro-9001 (28.33\%), these treatments were found at par each other. The Raj-171 was found to be badly infested ( $75.84 \%$ grain damage) which differed significantly over other varieties. The developmental period of the pest varied from $50.88-80.61$ days in different varieties, minimum being in Raj-171 and maximum in Pioneer 86 m 86.

\section{Introduction}

Pearlmillet, Pennisetum glaucum (Linn.) R. Br. emend Stuntz. (Family: Gramineae) is one of the important millet crops and comes next to sorghum in area and production. In India, it is grown in an area of 7.18 million hectares with an annual production to the tune of 9.73 million tonnes and average productivity of $1305 \mathrm{~kg} \mathrm{ha}^{-1}$ (Anonymous, 2017). The grains are nutritionally better than many cereals and good source of protein (12.6\%), fat (5\%), fibre (1.0\%) and minerals $(2.0 \%)$, chiefly Calcium, Phosphorus and Iron.

The grains in the storage are spoiled due to the infestation of organisms such as insects, mites and rodents causing heavy losses. In India, overall post harvest losses during storage and handling have been estimated to the tune of 9.33 per cent. However, Pareek et al. (2010) reported the quantitative loss due to different stored grain insect pests in pearlmillet from 2.50-22.36 per cent.

Among the insect pests, the Angoumois grain moth, Sitotroga cerealella Olivier; lesser grain borer, Rhyzopertha dominica (Fab.) and rice moth, Corcyra cephalonica Staint. are important. The rice moth, Corcyra cephalonica Staint. (Lepidoptera: Galleriidae) heavily infests the stored pearlmillet and distributed in Asia, Africa, North America and Europe. Besides pearlmillet, it feeds on rice, maize, wheat, groundnut, gram, cotton seed, sorghum etc. The larvae cause damage to the grain by feeding under silken webs. When infestation is high, the entire stock of grain may be converted into webbed mass, ultimately a characteristic foul odour is developed and qualitative and quantitative loss is caused.

The success achieved so far in making the stored grains free from insect pests has been largely on sole reliance of pesticides (Ghelani et al. 2009 and Arthur 2007). The indiscriminate use of fumigants and other toxic chemicals posed serious problems like chronic and acute toxicity, development of insect resistance, pest resurgence, residue in food stuff and hazards to human health and environmental pollution. There are encouraging reports on the use of some safer methods as grain protectant (Chander 
et al. 2000, Sharma and Bhargava 2001, Patel and Patel 2002, Pareek and Kumawat 2007 and Jacob and Qamar 2013).

To explore the safer methods with low cost for management of the pest was prime objective of the study. The common pearlmillet varieties were screened for resistance against the pest, $C$. cephalonica. The resistant varieties to the pest provide post harvest protection at free of cost. Such information was meagre, therefore, needed detailed investigation. It is a well known that certain varieties of the crops are less attacked by a specific insect pest than the others due to natural resistance. In integrated pest management, this phenomenon is exploited to suppress the pest population which is most important tool without incurring additional cost.

\section{Material And Methods}

The study was conducted in laboratory conditions at the Department of Entomology, S.K.N. College of Agriculture, Jobner during August, 2017 to July, 2018. The grain samples were weighed with the help of electronic balance. The moisture content of the seed samples was determined by the oven method (Khare 1994). A grain sample of $50 \mathrm{~g}$ was taken in the moisture box and dried at constant temperature till steady weight was observed. The moisture content of the grain samples were further verified from digital moisture meter (Green Agritech). The temperature of grain was determined with the help of grain thermometer by inserting it in bulk of the grain.

\section{Maintenance of insect culture}

The culture of rice moth, $C$. cephalonica was procured from the pure culture already going on at the Department of Entomology, S.K.N. College of Agriculture, Jobner. The grains were cleaned, surface rinsed with water, sun dried and then subjected for fumigation to eliminate any insect infestation, hidden or otherwise. These grains were conditioned for 48 hours at $29 \pm 1.5^{\circ} \mathrm{C}$ temperature and $75 \pm 5$ per cent relative humidity. The culture of $C$. cephalonica was developed on pearlmillet (variety, Raj.-171) from few identified individuals. For maintaining subsequent insect culture, 20 pairs of newly emerged adult insects were released for oviposition in the glass jar (size $30 \times 20 \mathrm{~cm}$ ) containing pearlmillet grain. Further, the newly emerged adults were transferred in a Matka bin containing conditioned grains in order to maintain a stock culture for continuous fresh supply of large number of moths and other insect stages required for the experimentation. For handling the infested grains and insects, a forceps and a camel hair brush was used. Every subsequent experiment was conducted at $29 \pm 1.5^{\circ} \mathrm{C}$ temperature and $75 \pm 5$ per cent relative humidity.

The seeds of different varieties of pearlmillet were procured from Pearlmillet Breeder, Rajasthan Agricultural Research Institute, Durgapura, Jaipur. A sample of $100 \mathrm{~g}$ grain of each variety was taken in glass jar $(250 \mathrm{ml})$, covered with muslin cloth and each replicated thrice. Two pairs of newly emerged moths were released in each glass jar having the seeds of different varieties. 
The observations were recorded on the grain damage caused by one generation $\left(F_{1}\right)$, adult emergence $\left(F_{1}\right)$, weight loss and total developmental period. The grain damage was recorded by visual observations. The adult emergence $\left(F_{1}\right)$ was recorded at every alternate day and accumulated at the end. The weight loss was recorded by excluding the frass from the grains. The total developmental period from adult to adult was recorded by averaging out the period.

The per cent data on grain damage and weight loss was transformed into angular values (arc sine

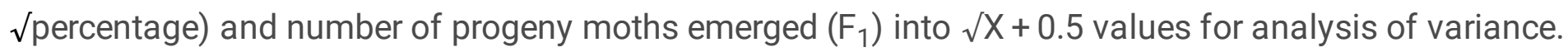
The susceptibility index (Dobbie index) was calculated as suggested by Dobbie (1977).

\section{Results And Discussion}

In present investigation, ten varieties of pearlmillet were observed for their reaction to $C$. cephalonica. The effective parameters were observed to screen them against $C$. cephalonica, i.e. adult emergence, grain damage, weight loss and total developmental period. The susceptibility or the Dobbie index was calculated in order to support the findings. The data indicated that none of the varieties was found free from $C$. cephalonica damage, although there exist a considerable difference among the resistance/ susceptibility among them. The adult emergence $\left(\mathrm{F}_{1}\right)$ in different varieties was observed in the range of 9.33-32.00, the minimum in Pioneer $86 \mathrm{~m} 86$ and maximum in Raj-171 which differed significantly over rest of the varieties (Table-1). The pioneer $86 \mathrm{~m} 86$ was followed by Pro agro- 9450 (10.33) and Pro agro9001 which were found at par each other. Maximum numbers of adults were emerged from Raj.171 and HHB-67 (32.00 and 30.00), respectively which were found at par each other.

The maximum seed damage was recorded in the Raj-171 (Table-1, Fig. 1), which differed non significantly with HHB-67 (72.12\%). The seed damage was minimum in Pioneer 86 m 86 (23.67\%) followed by Pro agro-9450 (25.55\%) and Pro agro-9001 (28.33\%). The weight loss recorded in different varieties due to incidence of $C$. cephalonica was in the range of $10.44-31.69$ per cent (Table-1, Fig. 1), the lowest in Pioneer $86 \mathrm{~m} 86$ which was found significantly superior over rest of the varieties, vis-a-vis highest in the Raj-171 (31.69\%).

The different varieties revealed a varied developmental period of $C$. cephalonica (adult to adult) which was in the range of 50.88-80.61 days, the minimum being in Raj-171 and maximum in Pioneer $86 \mathrm{~m} 86$, both differed significantly over rest of the varieties. The variety, Raj.171 was found non significant with Pioneer 86 m 38, Pioneer 86 m 84, Pro agro-9450 and HHB-67 (Table-1, Fig. 1). To reach a definite inference, the susceptibility index was computed which ranged from 2.77-6.82, the minimum in Pioneer $86 \mathrm{~m} 86$ and the maximum in Raj-171. The Pioneer $86 \mathrm{~m} 86$ was followed by Pro Agro 9450 and Pro Agro 9001. The work conducted on this aspect is meagre. Earlier Murugesan et al. (1997) reared $C$. cephalonica on ten varieties of pearlmillet and reported a significant difference between different varieties with $\mathrm{MH}-179$ giving a superior reproductive performance of $C$. cephalonica, probably because a greater lipoid content. In the present investigation, different varieties were taken which were other than 
those taken by Murugesan et al. (1997), therefore, the result could not get full support. However, the present findings got partial support from the findings of Pareek (2007). 
Table 1

Reaction of different varieties of pearlmillet to rice moth, Corcyra cephalonica Staint.

\begin{tabular}{|c|c|c|c|c|c|c|}
\hline S.No. & Varieties & $\begin{array}{l}\text { Adult } \\
\text { emergence } \\
\left(F_{1}\right)^{*}\end{array}$ & $\begin{array}{l}\text { Seed } \\
\text { damage } \\
(\%)^{\star \star}\end{array}$ & $\begin{array}{l}\text { Weight } \\
\text { loss (\%)** }\end{array}$ & $\begin{array}{l}\text { Developmental } \\
\text { period (Days)* }\end{array}$ & $\begin{array}{l}\text { Susceptibility } \\
\text { index }\end{array}$ \\
\hline \multirow[t]{2}{*}{1.} & RHB-173 & 26.67 & 65.41 & 28.12 & 61.25 & 5.36 \\
\hline & & (5.17) & (53.55) & (31.58) & $(7.82)$ & \\
\hline \multirow[t]{2}{*}{2.} & RHB-177 & 23.67 & 60.19 & 26.12 & 58.34 & 5.43 \\
\hline & & $(4.92)$ & (47.97) & (27.35) & (7.64) & \\
\hline \multirow[t]{2}{*}{3.} & $\begin{array}{l}\text { MPMH- } \\
17\end{array}$ & 25.33 & 61.42 & 26.82 & 56.42 & 5.73 \\
\hline & & $(5.04)$ & (51.01) & (30.54) & $(7.51)$ & \\
\hline \multirow[t]{2}{*}{4.} & HHB-67 & 32.00 & 72.12 & 31.15 & 52.51 & 6.60 \\
\hline & & $(5.66)$ & (57.49) & (33.30) & $(7.25)$ & \\
\hline \multirow[t]{2}{*}{5.} & $\begin{array}{l}\text { Pro Agro- } \\
9450\end{array}$ & 10.33 & 25.55 & 11.95 & 78.58 & 2.97 \\
\hline & & (3.22) & (30.36) & (20.22) & (8.85) & \\
\hline \multirow[t]{2}{*}{6.} & $\begin{array}{l}\text { Pro Agro- } \\
9001\end{array}$ & 10.67 & 28.33 & 12.60 & 70.33 & 3.37 \\
\hline & & (3.27) & (32.16) & (20.79) & (8.39) & \\
\hline \multirow[t]{2}{*}{7.} & $\begin{array}{l}\text { Pioneer } \\
86 \mathrm{~m} 86\end{array}$ & 9.33 & 23.67 & 10.44 & 80.61 & 2.77 \\
\hline & & (3.06) & (29.11) & (18.85) & (8.98) & \\
\hline \multirow[t]{2}{*}{8.} & $\begin{array}{l}\text { Pioneer } \\
86 \mathrm{~m} 84\end{array}$ & 30.33 & 60.25 & 30.51 & 57.12 & 5.97 \\
\hline & & $(5.51)$ & (50.33) & $(32.90)$ & $(7.56)$ & \\
\hline \multirow[t]{2}{*}{9.} & $\begin{array}{l}\text { Pioneer } \\
86 \text { m } 38\end{array}$ & 30.00 & 60.95 & 30.76 & 57.69 & 5.90 \\
\hline & & $(5.48)$ & (50.74) & (33.06) & (7.59) & \\
\hline \multirow[t]{4}{*}{10.} & Raj-171 & 32.00 & 75.84 & 31.69 & 50.88 & 6.82 \\
\hline & & (5.67) & (59.89) & (33.64) & (7.14) & \\
\hline & S.Em. \pm & 0.03 & 0.93 & 0.50 & 0.17 & - \\
\hline & $\begin{array}{l}C D(p= \\
0.05)\end{array}$ & 0.09 & 2.76 & 1.48 & 0.49 & - \\
\hline
\end{tabular}


* Figures in the parentheses are $\sqrt{ }(X+0.5)$ values.

** Figures in the parentheses are arc sine $\sqrt{ }$ percentage values.

\section{Declarations}

\section{Declarations}

The permission has been obtained from the authorities of national institute "Rajasthan Agriculture Research Institute, Durgapura, Jaipur" working under S K N Agriculture University, Jobner, Rajasthan. All the experimental protocols of study involving plant materials was conducted in accordance with the institutional, national and international guidelines and legislation under the methods section of manuscript. The seed material collect from "Rajasthan Agriculture Research Institute, Durgapura, Jaipur" and from the breeder Dr. L. D. Sharma.

\section{Acknowledgements}

The authors are grateful to the Dean, S.K.N. College of Agriculture (Sri Karan Narendra Agriculture University), Jobner, Jaipur (Rajasthan), India for providing necessary facilities to accomplish the study.

\section{References}

Anonymous Directorate of Economics and Statistics, Ministry of Agriculture and Farmers Welfare (Government of India, 2017).

Arthur, F. H., Liu, S. W., Zhao, B. G. \& Phillips, T. W. Residual efficacy of pyriproxyfen and hydroprene applied to wood, metal and concrete for control of stored product insects. Pest Manag, 65, 791-797 (2009).

Chander, H., Ahuja, D. K., Nagender, A. \& Berry, S. K. Repellency of different plant extracts and commercial formulations used as prophylactic sprays to protect bagged grain against Tribolium castaneum -a field study. J. Food Sci. Technol, 37, 582-585 (2000).

Dobbie, P. The contribution of the tropical study of insect resistance in stored maize. Trop. Stored Prod. Inf, 34, 7-22 (1977).

Ghelani, Y. H., Dhedhi, K. K., Joshi, H. J., Raghvani, K. L. \& Dangaria, C. J. Effect of insecticidal seed treatment on viability of pearlmillet seed during storage. Karnataka J. Agric. Sci, 22, 633-634 (2009). 
Jacob, P. \& Qamar, A. Reproductive impairment and lethal effects of selected combinations of some essential oils against the rice moth. Corcyra cephalonica. Eur. J. Exp. Biol, 3, 409-415 (2013).

Khare, B. P. (1994). Losses of produced commodity at post harvest handling, Stored Grain Pests and Their Management,Published by Kalyani Publishers, Ludhiana,pp.117-157

Murugesan, S., Sundararaj, R. \& Mishra, R. N. Varieties of pearlmillet for the maintenance of Corcyra cephalonica Staint. Culture towards the detrimental effect of the predatory habit of Tribolium castaneum (Herbst). Indian Forester, 123, 175-179 (1997).

Pareek, S. (2007). Ecofriendly management of Corcyra cephalonica Staint. on grain pearlmillet, Pennisetum glaucum (Linn.) R. Br.emend stunntz, Thesis submitted for partial fulfilment of M.Sc.(Ag) in Entomology to the SK Rajasthan Agricultural University, Bikaner.

Pareek, S. \& Kumawat, K. C. (2007). Evaluation of plant products as grain protectants against rice moth, Corcyra cephalonica Staint. on pearlmillet, Pennisetum glaucum (Linn.) R. Br. emend Stuntz. International Symposium on Organic Farming and Renewable Sources of Energy for Sustainable Agriculture' held in MPUAT, Udaipur from Nov.19-21, 2007.

Pareek, S., Choudhary, S. \& Kumawat, K. C. (2010). Qualitative and quantitative survey of insect pests of stored pearlmillet, Pennisetum glaucum (Linn.) R. Br. Emend Stuntz. National Conference on 'Plant Protection in Agriculture Through Ecofriendly Techniques and Traditional Farming Practices' held from 18-20 Feb. 2010 at Jaipur.

Patel, R. A. \& Patel, B. R. Evaluation of certain plant products as grain protectants against the rice moth, Corcyra cephalonica Staint in stored rice. Pest Mgt. Econ. Zool, 10, 121-124 (2002).

Sharma, K. C. \& Bhargava, M. C. Ovicidal effect of some growth distruption compounds on rice moth, Corcyra cephalonica Staint. Indian J.Appl. Ent, 15, 24-28 (2001).

\section{Figures}




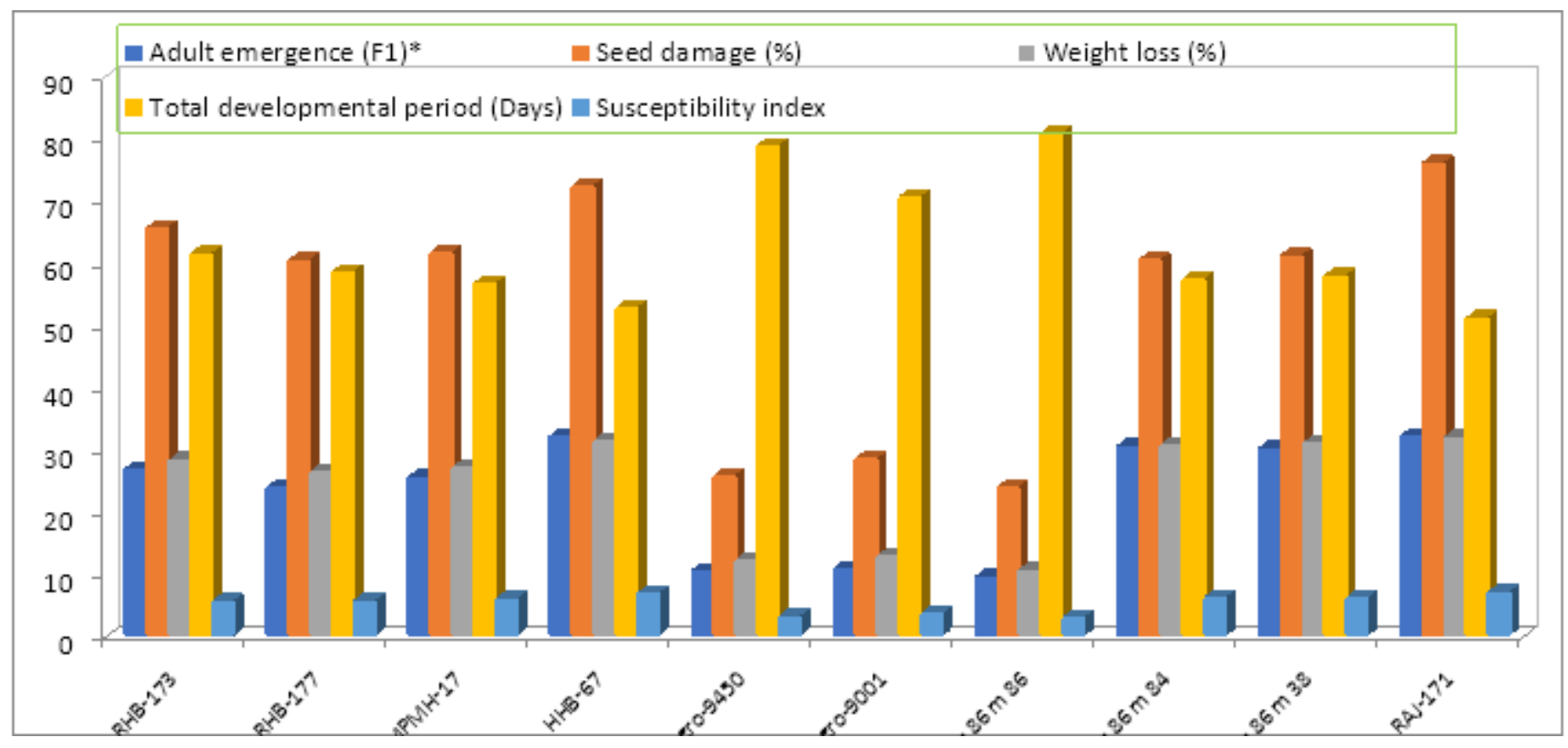

Figure 1

Reactions of different varieties of pearlmillet to rice moth, Corcyra cephalonica Staint. 